\title{
DECISION-MAKING ANALYSIS OF COMMUNICATION SYSTEM IN LIAONING PROVINCE
}

\author{
Su Dexiang and Yu Lige \\ Computer Center \\ of Liaoning Province and Economic Commission \\ Shenyang, China
}

\begin{abstract}
The decision-making analysis of communication system in Liaoning Province outlines the replica of the provincial communication system and its modelling process of investment analytic model by means of the point of view of system project and the method of systematic analysis. And, by way of man-machine dialogue, it makes prediction and decision-making analysis of transportation system of railway, highway, water navigation, aviation and tube transportation through the years from 1986 to 2000 .
\end{abstract}

\section{Preface}

Communication-transportation is a complicated system consisting of transportation modes such as railway, highway, water navigation, aviation and tube transport. Liaoning's communication system has developed into a combined transport system with complete varieties that radiate in all directions and makes Liaoning one of the Provinces in China that communications have most developed.

The present article outlines the replica of the Provincial communications system and its modelling process of investment analytic model by using the point of view of system project and the systematically analytic method and, by way of man-machine dialogue, it provides the decision-making departments with predictions of more than twenty varieties of targets in communications system, plans for investment required to realize predicated target and their feasiablity analysis.

On the basis of the data on communications within the Province in 1985, screening some relevant historical data and using the above said method, the present article predicts and makes decision-making analysis of the transport systems of railway, highway, water navigation, aviation and tube transist from the year 1986 through to the year 2000 within Liaoning Province and its results have been adopted by departments concerned.

\section{Status quo of Liaoning's Communications System}

Liaoning is a multi-citied province with industry and agriculture much developed. Located at the vital communications line between the Northeast and the rest part of China" west to the Shanhaiguan Pass, the province has large volumes of production and traffic flows. Running within the province are six major railway lines of Shenyang-Shanhaiguan, Changchun-Dalian and etc. and twenty-eight branches. Railway operative milage in 1985 is $3538 \mathrm{~km}$, accounting for $7 \%$ of the country's total milage; while highway service milage is $33006 \mathrm{~km}, 4 \%$ of the nation's total; The coast line in the provice is $2178 \mathrm{~km}$, with Dolian, Yingkou and other four sea ports. Wharf line in harbours is $16242 \mathrm{~m}$ in length with 148 berths, among which, 28 are of 10,000 tonage, accounting for $14 \%$ of the country's total 10,000-ton berths. Dalian is the second sea port in China and there are four air ports for civil aviation in Shenyang and Dalian 
and other cities in the Province. 18 inland air lines and one international air line ure opened in the Province with $22800 \mathrm{~km}$ of air service milage. In the Province, there are $1419.6 \mathrm{kms}$ of oil pipeline, accouting for $12.1 \%$ of the nation's total length.

In 1985 the entire Province accomplished transportation of 235 million tons of various cargoes, accounting for $8.7 \%$ of the nation's total capacity; the cycling amount of cargo is $119.78 \%$ billion ton $/ \mathrm{km}, 6.3 \%$ of the nation's total; passenger transport is 360 million people; $6.3 \%$ of the nation's' total; cycling capacity of travellers is $\mathbf{3 0 . 5 5}$ billion person $/ \mathrm{km}$, accounting for $7.1 \%$ of the nation's total; Its harbour's handling capacity is 50 million ton, $14.6 \%$ of the nation's coastal sea ports.

\section{Modelling System of Decision-Making Analysis of Liaoning Provincial: Communication System}

The modelling system of decision-making analysis of Liaoning Provincial communications system contains of three models: ITSDM model, LTSAM model and LTEAM model. The relevant indicators in strategic plans for the entire province's economic development given by the provincial macro-economic model, such as production, speed and investment, etc. act as external variants of system input, while some indicators of the annual communication system with 1985 as base period are taken as input variants. They are put into LTSD:M and LTSAM models respectively to predict the indicators for transport amount, cycling amount, investment, new equipments added, etc. in the total provincial communication system from 1986 through to the year 2000. Some feasiable plans were selected by means of screening according to the operator's intention through the dialogue between system analysis and the control panel (if no feasiable plans are available, system returns to imput end, correct input parameter, and go on with the above operation process). Indicators were put into LTEAM model, analysis and evaluation were conducted according to indicators and then good and bad plans were selected. Decision-making plans were determined through dialogue again between system analysis and control desk (if no optinmum plan is available, system returns and repeat the above said process). Then the plans were provided to decision-making department. Its process is as shown in Fig. 1.

\section{a. LTSDM model}

LTSDM model is the SD replica of Liaoning Provincial communication system, a system dynamic model consisting of 63 variants, 250 strong equations and transport modes including railway, highway, water navigation, aviation and simulates.

\section{b. LTSAM Model}

LTSAM Model is the analytic model set up by means of AHP for investment in Liaoning Provincial communication system. Its structure is shown in Fig. 3.

Creterion stratum: Weights in total investment in comminication and transportation in the five major transport departments from $\mathrm{Zl}$ to $\mathrm{Z5}$.

Sub-creterion stratum: the six influential factors that are: S1 to S5.

Stratum of plans: FI to F10 is the orientation for major investment in construction of communication system. Scale that judges the matrix is determined by means of the combination of qualitative and quantitative methods. In quantitative method, historical data was used to obtain proportional relation between two factors in corresponding stratum and then, by means of qualitative method to ask for opinions form experts in decision making departments for modification. In investment in railway, for instance, the function of proportional relation with total investments 
in the whole province in every past year is easy to obtain. The proportion of relation function thus obtained is to be compared with the proportion obtained with LTSDM Model. Then we asked for opinions from expers concernedfor correction so as to determine a proper proportion. For the rest factors, this method is also used to determine the proportion to set up a ratio table of relations among factors. The table, then, was converted into table of difference among all factors by means of Thurstone method, and the scale table can beobtained by coverting the table of difference to some extent and the judging matrix is constructed.

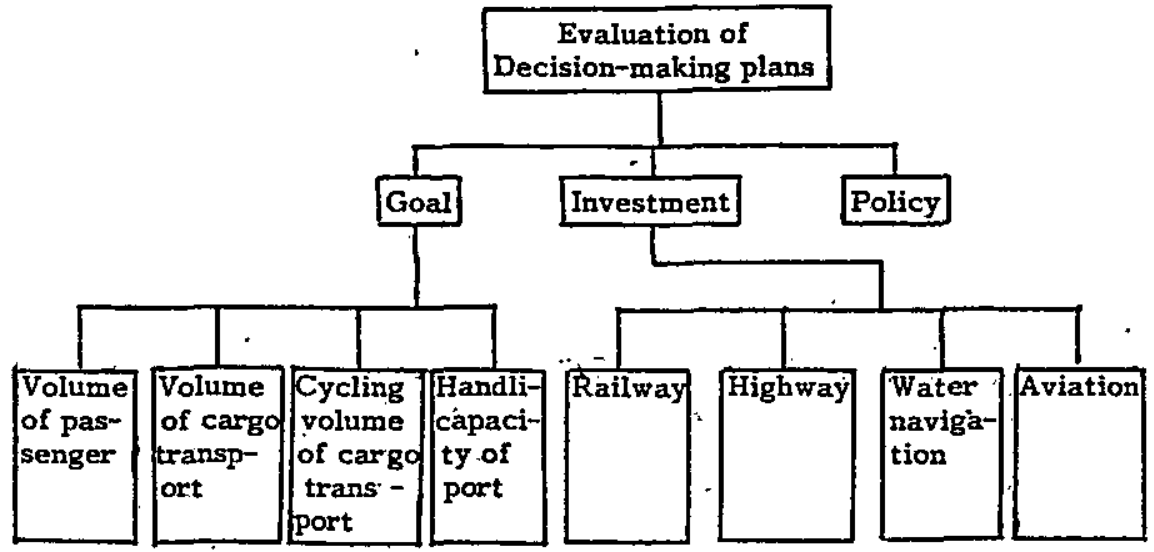

Fig. 3'. LTEAM Model for Evaluation of Decision-Making Plans for Liaoning Provincial Communicatin System

\section{c. LTEAM Model}

The LTEAM Model is also a model set up by means of AHP method for stratum analysis of evaluation of the decision-making

The evaluation indicators and stratum are shown in Fig. 4. Determination of judging matrix is done in combination of analysis of historical data with experts' appraisal. Having been computed, the model is multiplied by a weighted number which, having been properiy treated, is shown in Table 1 of the initial weighted values of evaluation indicators.

Evaluation of indicators in Table 1 is done by means of elastic coefficients which are:

$$
\varepsilon_{i}=\frac{\Delta s_{i}}{\Delta M_{i}}
$$

where $E_{i}$ is the elastic coeffients in $i$ lines of, evaluation indicators,

$\Delta s_{i}$ is the annual growth of $i$ lines of evaluation indicators,

$\Delta M$ is the annual grow th of GNP.

According to historical quantitative level of $\varepsilon_{i}$, the optimum was selected as evaluation standard that is suitable for the provincial conditions. The highest sub-values aregivenas 9 , with the rest progressively decreasing as. $7,5,3,2,1$. The standard values of our evaluation are given in table 2. 
Table 2 Standard values for 6 selection.

\begin{tabular}{|l|c|}
\hline $\begin{array}{l}\text { Evaluation } \\
\text { indicators }\end{array}$ & value \\
\hline $\begin{array}{l}\text { Volume of } \\
\text { passenger } \\
\text { trnsport }\end{array}$ & 1.0 \\
\hline $\begin{array}{l}\text { Volume of } \\
\text { cargo } \\
\text { transport }\end{array}$ & 1.0 \\
\hline $\begin{array}{l}\text { Cycling } \\
\text { volume of } \\
\text { passenger } \\
\text { transport }\end{array}$ & 1.0 \\
\hline $\begin{array}{l}\text { Cycling } \\
\text { volume of } \\
\text { cargo } \\
\text { transport }\end{array}$ & 0.9 \\
\hline $\begin{array}{l}\text { Yort han- } \\
\text { dling } \\
\text { capacity }\end{array}$ & 0.9 \\
\hline
\end{tabular}

\begin{tabular}{|c|c|}
\hline $\begin{array}{l}\text { Evaluation } \\
\text { indicators. }\end{array}$ & value \\
\hline $\begin{array}{l}\text { Investment } \\
\text { in highway }\end{array}$ & 0.5 \\
\hline $\begin{array}{l}\text { Investment } \\
\text { in hịghway }\end{array}$ & 0.7 \\
\hline $\begin{array}{l}\text { Investment } \\
\text { in } \\
\text { navigation }\end{array}$ & 0.6 \\
\hline $\begin{array}{l}\text { Investment } \\
\text { in } \\
\text { aviation }\end{array}$ & 0.5 \\
\hline $\begin{array}{l}\text { Investment } \\
\text { in tube } \\
\text { transport }\end{array}$ & 0.3 \\
\hline
\end{tabular}

The weights of all evaluation indicators in Table 1 is to be multiplied respectively by corresponding value and, then to obtain tne total sum, which is:

$$
N=\sum_{i=1}^{5} w_{1 i} \varepsilon_{1 i}+\sum_{j=1}^{5} w_{2 j} \varepsilon_{2 j}
$$

where

N is the standard sub-value of the comprehensive evaluation of the decisionmaking plaas,.

$W_{1 i}$ are respectively the weight and standard sub-value of the goal of deciston-making (volume of passenger transport, ....)

$W_{21}$ are respectively the weights and standard sub-value of investment plans fot dejcision-making (railway, ....)

Pollcy factors are not quantifled. Condition for materilization of all plans and games respectively taken for them could only be determined by decisionmaking departments. Through above said steps, the evaluated mark points of plans calculated were their sub-value and, then, were provided to the decision-. making department.

\section{The Decision-making Analysis of Liaoning Provincial Commuication System}

Through calculation, Anilysis and evaluation, the situation of Liaoning's communication and transportation in the year 2000 is as follows :

1. Transport lines and transport tools

Rallway: milage of railroad service in the province will be as much as $4100 \mathrm{Km}$, the modified and expanded electric railway being $500 \mathrm{Km}$, with 1665 locomotives and 2368 passenger trains. 
Highway: gervice mllage will be $43669 \mathrm{Km}$, with $1084 \mathrm{Km}$ of class A highway among it.

Society will have in possession 600,000 vehicles.

Port: along the coast.there will be 204 berths, with 50 of them being 10,000ton grade.

Aviation: there will be additional 20 inland alrlines and 2 international airlines.

Tube transport: $500 \mathrm{~km}$ of oil pipelfne will be constructed for oll final product.

2. Yolume of cargo Transport and Passenger Transport

Volume of passenger transport: will be 1.02 billion people, 2.5 times that of 1985, annual growtn being 6.4\%. Among them, transport by raflway will be 290 million people, 730 million by highway, 400,000 people by water navigation and 4 million by aviation.

Volume of cargo trangport; will be 1.85 billion ton, 2.7 times that of 1985 , annual growtn being $6.8 \%$. Among it, 220 million ton will be transported by rallway, 1.57 billion ton by highway, 2 mflilon ton by navigation and 60 nilition bon by tube.

3. Cycling volume of cargo and passenger transports

Passenger: will be 66.2 biliton people. Km, 2.1 times that of 1985 with annual growth being $5 \%$. Among it, 42.2 bllilion people. $\mathrm{Km}$ by rallway, 19.8 biltion people. $\mathrm{Km}$ by highway, 30 militon people by water. navigation and 4.2 billion. people. $\mathrm{Km}$ by clvil aviation.

Cargo: will be 269.2 billion ton. $\mathrm{Km}, 2.2$ times tnat of 1985, annual growth being $5.5 \%$. Among it, 1y1.5 billion ton $/ \mathrm{km}$ is done by rallway, 47 billion ton $/ \mathrm{km}$ highway, 2.47 bfllion ton/Km by water navigation, 70 milition ton. $\mathrm{Km}$ by civil and 28.2 billion ton. $\mathrm{Km}$ by tube.

4. Sea port handilng capactty

By the year 2000, harbour handling capacity of Province will be 130 militon ton, 3 times that of $1 \times 85$, with annual growth being $7.4 \%$.

5. Investment

According to prediction, by the year 2000, the accumulaced investment in capital construction of conmunication system will be 19.2 billion yuan (RBM) to meet the need of the sum, 3.1 bilition will be In ratlway, 8.9 billion Yuan in highway, 4.5 billion for water navigation, 2.4 billion for aviation and 300 million yuan for tube.

6. The Feasibilfty analysis of plans

Through evaluation, mark points of the above pians are as high as 835 points, the highesp among nearly one hundred plans.

Disctsston of experts concerned concluddd that to realize this plan investment must be increased, the existing transport administrative system be reformed, productivity hightened, technfcal transfiormation by enhanced and transport capacity and efriclency be raised, transportacion system must be equiped 
with advanced technology and equipments and regulations and rules in communication and transportation must be set up and perfected. Th1s plan will be reallzed easily. so long as measurements are properly taken.

\section{References}

1. Jay. W. Forrester 〈〈World Dynamics〉〉 Wright-Allen Press, INC 1971

2. Xie Changhong 〈System Dynamics〉 ---Theory, method and practice--Zhongxing Adminfotrative Consulting Inc.

3. Liu Bao < Quantitative Method For Evaluating Comprehensively the Scientiflc Achievements $\gg$ System Project Research Institute, Tianjin University, 1984.

4. Min Jiansu and You Hanming 〈〈Market Study---Basic Methed〉〉 Chinese University Pres 8, Hon Kong, 1979.

5. Su Dexiang and Yu Lige 〈〈Liaoning ${ }^{\prime} B$ Communication in the Year 2000〉〉 Lfaoning In 2000 Study Group, August 1987

8

ठ 